\title{
Determinants of acquiring malaria among displaced people in Khartoum state, Sudan
}

I.E. Saeed ${ }^{1}$ and E.S. Ahmed ${ }^{2}$

$$
\begin{aligned}
& \text { محدِّدات اكتساب عدوى الملاريا بين النازحين حول ولاية الحخرطوم في السودان }
\end{aligned}
$$

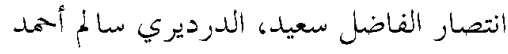

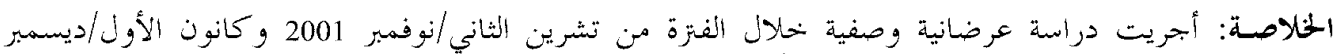

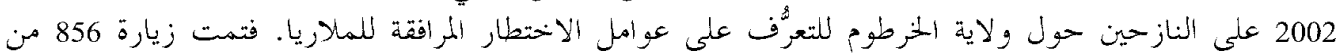

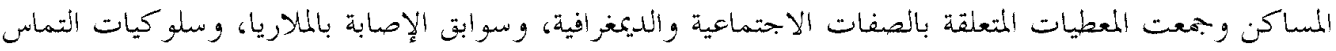

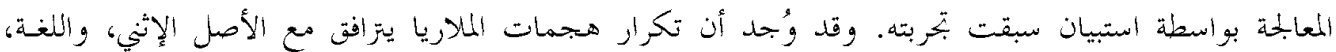

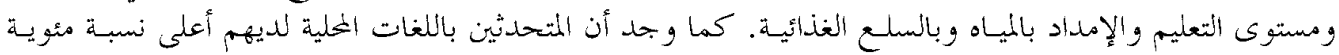

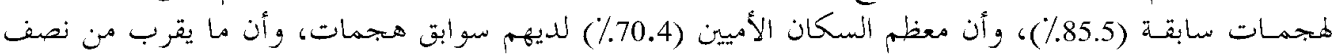

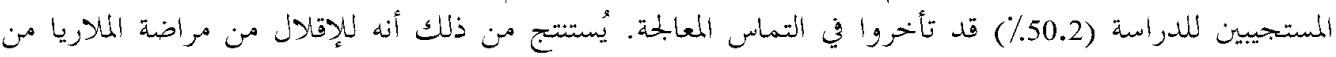

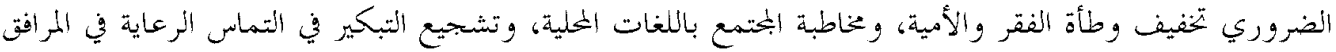

$$
\begin{aligned}
& \text { الصحية، وتحسين الإملاد بالمياه. }
\end{aligned}
$$

ABSTRACT A cross-sectional descriptive study was carried out among displaced people in Khartoum state to determine risk factors associated with malaria. Data were collected from 856 households about sociodemographic characteristics, history of malaria, and knowledge, attitudes and treatment-seeking behaviour. Overall, $68.2 \%$ reported a malaria attack among household members in the previous year. Risk of malaria attack was significantly associated with tribe, language, education, water supply and food expenditure. The highest rates of attack were among local language speakers (85.5\%) and illiterate residents $(70.4 \%)$. Half the respondents $(50.2 \%)$ delayed seeking treatment for malaria. Knowledge, attitudes and practices had no association with malaria attacks, except for a 4.7 -fold increased risk of malaria when obtaining water from carts rather than wells.

Facteurs d'acquisition du paludisme parmi les populations déplacées dans l'Etat de Khartoum (Soudan)

RESUME Une étude descriptive transversale a été réalisée parmi les populations déplacées dans l'Etat de Khartoum pour déterminer les facteurs de risque associés au paludisme. Des données ont été recueillies auprès de 856 foyers en ce qui concerne les caractéristiques socio-démographiques, les antécédents de paludisme, ainsi que les connaissances, les attitudes et les comportements en matière de consultation. Le risque d'accès de paludisme était significativement associé à l'origine ethnique, à la langue, à l'instruction, à l'approvisionnement en eau et aux dépenses en nourriture. On trouvait les plus forts pourcentages d'accès de paludisme chez les personnes parlant la langue locale $(85,5 \%)$ et chez les résidents analphabètes $(70,4 \%)$. La moitié des répondants $(50,2 \%)$ avait tardé à consulter. II n'y avait aucune association entre les connaissances, attitudes et pratiques et les accès de paludisme, à l'exception d'une augmentation du risque de paludisme de 4,7 fois lorsque l'eau était approvisionnée par charrettes plutôt que de puits.

${ }^{1}$ Centre for Science and Technology, Ahfad University for Women, Omdurman, Sudan.

${ }^{2}$ Department of Microbiology and Parasitology, College of Medicine, University of Juba, Juba, Sudan.

المجلة الصحية لشرق المتوسط، منظمة الصحة العالمية، المجلد التاسع، العدد ؟، ب..T 


\section{Introduction}

Globally, the malaria situation is serious and still deteriorating. Malaria predominantly affects the poor and underprivileged. About $90 \%$ of all malaria deaths in the world today occur in Africa south of the Sahara. An estimated 1 million people in Africa die from malaria each year and most of these are children under 5 years old [1]. In the endemic countries, $25 \%-40 \%$ of all outpatient clinic visits are for malaria (with most diagnoses made clinically). In these same countries, between $20 \%$ and $50 \%$ of all hospital admissions are a consequence of malaria.

Poor people are at increased risk both of becoming infected with malaria and of becoming infected more frequently. Child mortality rates are known to be higher in poorer households and malaria is responsible for a substantial proportion of these deaths. In Tanzania, mortality in under 5year-olds following acute fever (much of which would be expected to be due to malaria) was 39\% higher in the poorest socioeconomic group than in the richest [2]. In Zambia also, a substantially higher prevalence of malaria infection was found among the poorest population groups [3].

Malaria epidemics have become a regular occurrence in many parts of the world, being associated with the warming of climate, disruption of health services and large-scale uncontrolled population movement as a result of social disruption and civil war. The economic impact of malaria is borne particularly by those in the poorest countries of the world and among populations living under the most difficult conditions [4]. In malarious areas, exposure to malaria transmission in refugees is several times greater than that of local people living under normal conditions (J.A. Nájera, unpublished data, 1977).
In Sudan, malaria accounts for $25.7 \%$ of total hospital admissions and $15.9 \%$ of total deaths [5]. Displaced populations in southern Sudan suffer from a high incidence and prevalence of malaria. Moreover, the presence of chloroquine-resistant malaria aggravates the problem [6].

Information regarding the links between socioeconomic factors and malaria, particularly in displaced people in Khartoum state, is scarce. Therefore, this study was carried out in order to determine these relationships. Our objectives were to determine the factors associated with malaria among these populations and to assess knowledge, attitudes and practices regarding transmission, disease, treatment and prevention of malaria.

\section{Methods}

\section{Study area}

Khartoum state, located in the northern part of central Sudan, is the most economically important state in the country. The estimated population of Khartoum state is 5135414 (population data sheets, UNFPA and Central Bureau of Statistics, 2003). In Sudan there are about 2 million displaced people, of whom approximately 400000 are resident in 4 camps in Khartoum state (Jabal Awlia, Mayo, Dar El Salam and Wad El Bashir) and 2 replanned areas (Cartoon Kassala and Id Babiker). The study was carried out in 2 of these locations, Jabal Awlia camp and Cartoon Kassala camp.

Jabal Awlia camp is situated $40 \mathrm{~km}$ south of Khartoum and contains 8000 households. During the period of the study, there were 4 basic and 1 secondary schools. Health services are provided by nongovernmental organizations (NGOs) in 5 clinics. The water supply is from wells operated by hand pumps. There are 3 private farms near the camp.

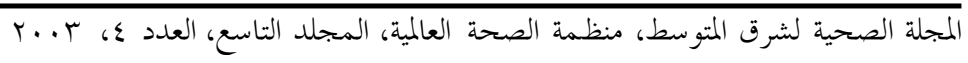


Cartoon Kassala camp (replanned area) has 25000 households and is situated $7 \mathrm{~km}$ north of Khartoum. It was established in 1990 and replanned in 1999. Health services are provided predominantly by NGOs. The source of water is wells operated by hand pumps or distribution from vending carts.

\section{Study population}

The majority of the study population were women and children who migrated from their homeland due to famine and war between 1983 and the present day. The mean number of family members per household was 6 individuals (population data sheets, UNFPA and Central Bureau of Statistics, 2003). The people work mainly as informal, marginal and unskilled workers, and come from different tribes with various cultures.

\section{Study design}

A cross-sectional descriptive study was carried out during the period November 2001 to December 2002.

Stratified, systematic, random sampling was used for selection of houses, the sample size for each camp being proportionate to the population of the camp. The study was launched via a meeting with community leaders and community health promoters. A team of well-trained and closely supervised local interviewers conducted the household survey using a pre-tested questionnaire to interview the head of each household. At each household the aim of the study was clearly explained and informed consent was obtained from the head of the family. Interviewers collected demographic, social and behavioural data. Information about the number of malaria attacks suffered by household members during the previous year was also recorded. Data about malaria deaths among the household members is reported in another paper [7].

Variables used for assessing respondents' knowledge included: definition of malaria, cause of malaria, whether it is treatable, whether it causes death, mosquito breeding sites, malaria treatment, adult dose of chloroquine, child dose of chloroquine and malaria symptoms in adults and in children. Variables used for assessing attitudes and practices included: concern about malaria, means of keeping mosquitoes away, use of bednets, the first action when feeling malaria symptoms or noticing symptoms in their children, the second action when feeling malaria symptoms or noticing symptoms in their children, drug use, stopping treatment before improvement and use of traditional remedies.

The responses were scored 1 for a correct answer and 2 for an incorrect answer. Total scores were calculated for 3 domains-knowledge; attitudes and practices; and treatment-seeking behaviour-and these were classified as 'good' if the total score was less than the median for the sample and 'poor' if greater than the median. Data analysis was carried out using SPSS, version 9.0. First a descriptive statistical analysis was carried out. Univariate analysis (chi-squared test) was applied to compare between proportions and to produce an estimate of the odds ratio associated with each factor, and multivariate (logistic regression) analysis was performed to find any association between variables and to obtain the adjusted odds ratio for the final model.

\section{Results}

A total of 856 household heads were interviewed during the survey, 272 from Jabal Awlia and 584 from Cartoon Kassala camp.

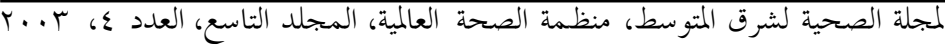




\section{Sociodemographic characteristics}

The sociodemographic characteristics of the respondents are shown in Table 1 . Females constituted $85.7 \%$. Of the interviewees, $85.4 \%$ were married, $6.0 \%$ single, $2.3 \%$ divorced and $6.3 \%$ widowed. Just over half were illiterate (56.1\%) and $32.6 \%$ were semi-literate. The respondents' levels of education differed significantly between the 2 camps and was lower in Cartoon Kassala. As regards women's occupation, $72.5 \%$ were housewives, 24.7\% were informal labourers, and 2.2\% were students. The mean number of children per household was 4 and $64.1 \%$ of households had more than 2 children. The majority of the respondents (68.9\%) were between 21 and 40 years old. Housing conditions (construction materials, windows, surrounding walls, number of rooms) differed greatly between the 2 camps, being poorer in Jabal Awlia than in Cartoon Kassala.

The dominant tribes in the 2 camps were from the southern part of Sudan (59.1\%), the rest were predominantly from the western part. The main languages spoken in Jabal Awlia and Cartoon Kassala were Dinka (a local language) and Arabic.

The entire population of Jabal Awlia obtained water from public hand pumps, whereas in Cartoon Kassala 69.2\% obtained water by cart and the rest obtained it from public hand pumps. Only 3.1\% of the Cartoon Kassala households and none of Jabal Awlia keep water for more than a week.

A free health service is provided by NGOs for $55.5 \%$ of respondents in Jabal Awlia and 40.1\% in Cartoon Kassala, although some health centres charge a small fixed fee per patient for drugs.

\section{Knowledge}

The score for good knowledge about malaria among the heads of households in the displaced camps was $56.8 \%$. The percentage of interviewees with good knowledge in Jabal Awlia (71.7\%) was significantly higher than in Cartoon Kassala (49.8\%). In contrast, attitudes and treatment-seeking behaviour in Cartoon Kassala were significantly better than in Jabal Awlia (Table 2).

Out of 856 respondents, $96.7 \%$ believed malaria was a serious disease, and 83.8\% identified fever as the most common symptom associated with malaria. Other symptoms (rigors, vomiting, diarrhoea and headache) were more frequently associated with malaria by inhabitants of Jabal Awlia camp. Chloroquine as a treatment for malaria was stated by $72.2 \%$ of the respondents.

Mosquito bites were mentioned as the cause of malaria by $72.8 \%$ and $79.1 \%$ of respondents in Jabal Awlia and Cartoon Kassala camps respectively. Mosquito breeding sites were correctly described by $86.7 \%$ of total respondents.

\section{Attitudes and practices}

The principal method used by respondents in both camps to keep mosquitoes away was burning of herbs, used by 402 (47.0\%), followed by use of bednets by $18.8 \%$ (161), whereas spraying was used by only $14.6 \%$ (125). Other methods were used by $19.6 \%$ (mixture of burning of herbs plus spray or oil).

In total, $64.3 \%$ (550) of respondents stated that they never use bednets, while only $20.8 \%$ mentioned that children sleep under bednets (mother 1.9\%, father 2.1\%, mother and children $8.8 \%$, all family members $2.2 \%$ ). The proportion of respondents 
\begin{tabular}{ll}
\hline Eastern Mediterranean Health Journal, Vol. 9, No. 4, 2003 & $\mathbf{5 8 5}$
\end{tabular}

Table 1 Sociodemographic characteristics of the heads of households interviewed in Jabal Awlia and Cartoon Kassala camps

\begin{tabular}{|c|c|c|c|c|c|}
\hline Characteristic & $\begin{array}{l}\text { Total } \\
\text { No. }\end{array}$ & $\begin{array}{c}\text { Jabal Awlia } \\
\text { No. (\%) }\end{array}$ & $\begin{array}{c}\text { Cartoon Kassala } \\
\text { No. (\%) }\end{array}$ & $\dot{\circ}^{2}$ & $P$-value \\
\hline \multicolumn{6}{|l|}{ Sex } \\
\hline Male & 122 & $63(23.2)$ & $59(10.1)$ & 25.8 & $<0.001$ \\
\hline Female & 734 & 209 (76.8) & 525 (89.9) & & \\
\hline \multicolumn{6}{|l|}{ Age (years) } \\
\hline$<21$ & 136 & $27(9.9)$ & $109(18.7)$ & 28.3 & $<0.001$ \\
\hline $21-40$ & 590 & $183(67.3)$ & 407 (69.7) & & \\
\hline $41-60$ & 116 & $52(19.1)$ & $64(11.0)$ & & \\
\hline$>60$ & 14 & $10(3.7)$ & $4(0.7)$ & & \\
\hline \multicolumn{6}{|l|}{ Tribe } \\
\hline Dinka & 326 & 107 (39.3) & 219 (37.5) & 126.5 & $<0.001$ \\
\hline Nuba & 223 & $127(46.7)$ & $96(16.4)$ & & \\
\hline Western tribes & 127 & $27(9.9)$ & $100(17.1)$ & & \\
\hline Southern tribes & 180 & $11(4.0)$ & 169 (28.9) & & \\
\hline \multicolumn{6}{|l|}{ Language } \\
\hline Dinka only & 159 & $36(13.2)$ & $123(21.1)$ & 9.6 & $<0.01$ \\
\hline Dinka + other loc & & & & & \\
\hline+ Arabic & 635 & $210(77.2)$ & $425(72.8)$ & & \\
\hline Arabic & 62 & $26(9.6)$ & $36(6.2)$ & & \\
\hline \multicolumn{6}{|l|}{ Martial status } \\
\hline Married & 731 & $217(79.8)$ & $514(88.0)$ & 44.3 & $<0.001$ \\
\hline Single & 51 & $8(2.9)$ & $43(7.4)$ & & \\
\hline Divorced & 20 & $10(3.7)$ & $10(1.7)$ & & \\
\hline Widowed & 54 & $37(13.6)$ & $17(2.9)$ & & \\
\hline \multicolumn{6}{|l|}{ Number of children } \\
\hline $1-2$ & 307 & $98(36.0)$ & $209(35.8)$ & 0.94 & 0.005 \\
\hline $3+$ & 549 & $174(64.0)$ & $375(64.2)$ & & \\
\hline \multicolumn{6}{|l|}{ Education } \\
\hline Illiterate & 480 & $184(67.6)$ & $296(50.7)$ & 25.7 & $<0.001$ \\
\hline Basic & 279 & $63(23.2)$ & $216(37.0)$ & & \\
\hline Secondary & 80 & $24(8.8)$ & $56(9.6)$ & & \\
\hline Higher & 17 & $1(0.4)$ & $16(2.7)$ & & \\
\hline \multicolumn{6}{|c|}{ Presence of windows } \\
\hline Yes & 756 & 255 (93.7) & $501(85.8)$ & 11.4 & $<0.01$ \\
\hline No & 100 & $17(6.3)$ & $83(14.2)$ & & \\
\hline \multicolumn{6}{|l|}{ Type of building } \\
\hline Bricks & 23 & $3(1.1)$ & $20(3.4)$ & 3.9 & $=0.135$ \\
\hline Clay & 811 & $261(96.0)$ & $550(94.2)$ & & \\
\hline Shelter & 22 & $8(2.9)$ & $14(2.4)$ & & \\
\hline
\end{tabular}

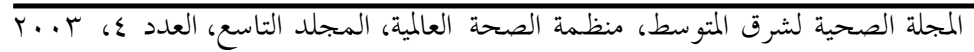




\begin{tabular}{|c|c|c|c|c|c|}
\hline Characteristic & $\begin{array}{l}\text { Total } \\
\text { No. }\end{array}$ & $\begin{array}{c}\text { Jabal Awlia } \\
\text { No. (\%) }\end{array}$ & $\begin{array}{c}\text { Cartoon Kassala } \\
\text { No. (\%) }\end{array}$ & $\dot{\circ}^{2}$ & $P$-value \\
\hline \multicolumn{6}{|c|}{$\begin{array}{l}\text { Presence of surrounding } \\
\text { walls }\end{array}$} \\
\hline Yes & 648 & $167(61.4)$ & $481(82.4)$ & 44.3 & $<0.001$ \\
\hline No & 208 & $105(38.6)$ & $103(17.6)$ & & \\
\hline \multicolumn{6}{|l|}{ Number of rooms } \\
\hline $1-2$ & 575 & 201 (73.9) & $374(64.0)$ & 8.1 & $<0.01$ \\
\hline$>2$ & 281 & $71(26.1)$ & $210(36.0)$ & & \\
\hline \multicolumn{6}{|l|}{ Source of water } \\
\hline Well & 452 & $272(100)$ & $180(30.8)$ & 356.3 & $<0.001$ \\
\hline Cart & 404 & 0 & $404(69.2)$ & & \\
\hline \multicolumn{6}{|l|}{ Keeping water } \\
\hline$>1$ week & 18 & 0 & $18(3.1)$ & 26.3 & $<0.001$ \\
\hline 1 week & 30 & 0 & $30(5.1)$ & & \\
\hline$<1$ week & 5 & 0 & $5(0.9)$ & & \\
\hline Don't keep & 803 & $272(100)$ & $531(90.9)$ & & \\
\hline \multicolumn{6}{|l|}{ Food expenditure } \\
\hline No income & 35 & 17 (6.3) & $18(3.1)$ & 61.3 & $<0.001$ \\
\hline $50 \%$ & 201 & $29(10.7)$ & $172(29.5)$ & & \\
\hline $33 \%$ & 64 & $13(4.9)$ & $51(8.7)$ & & \\
\hline $25 \%$ income & 20 & 0 & $20(3.4)$ & & \\
\hline All income & 536 & 213 (78.3) & $323(55.3)$ & & \\
\hline
\end{tabular}

always using bednets in Cartoon Kassala, $26.5 \%$ (155), was much greater than in Jabal Awlia, 18.4\% (50). The price of bednets was stated to be unaffordable by $62.5 \%$ (170) and 40.8\% (238) of the residents in Jabal Awlia and Cartoon Kassala camps respectively.

Health centres were cited as the first resort for malaria treatment by 373 respondents, 23.5\% in Jabal Awlia and 63.9\% in Cartoon Kassala. Delays of 2 or more days in seeking treatment for malaria at health services were mentioned by 430 (50.2\%) respondents, while 54 (6.3\%) stated that they never use the heath services. Reasons mentioned for delay in seeking treatment were lack of money (18.5\%), waiting for improvement (24.4\%), and waiting for the effect of traditional remedies (6.5\%). Treatment-seeking behaviour was significantly different between tribes, being poor among 199 (61.0\%) Dinka, 153 (68.6\%) Nuba, 68 (53.5\%) people from western tribes and $113(62.8 \%)$ people from southern tribes $\left(P<0.05, \chi^{2}=8.16\right)$.

For self-medication $18.8 \%$ (161) used antipyretics, $11.4 \%$ (98) used chloroquine and $18.2 \%$ (156) used traditional remedies The proportion of users of traditional remedies was higher in Jabal Awlia (31.6\%) than in Cartoon Kassala camp (12.0\%). The use of traditional remedies was reported among 20.9\% (68) of Dinka, 24.7\% (55) of Nuba, $9.4 \%$ (12) of people from western tribes

المجلة الصحية لشرق المتوسط، منظمة الصحة العالمية، المجلد التاسع، العدد ع، ب... 


\begin{tabular}{|c|c|c|c|c|c|}
\hline \multirow[t]{2}{*}{ Determinant } & \multirow{2}{*}{$\begin{array}{l}\text { Total }^{\mathrm{a}} \\
\text { No. }\end{array}$} & \multicolumn{2}{|c|}{ Good score ${ }^{b}$} & \multirow[t]{2}{*}{$\dot{\div}^{2}$} & \multirow[t]{2}{*}{$P$-value } \\
\hline & & No. & $\%$ & & \\
\hline \multicolumn{6}{|l|}{ Knowledge } \\
\hline Jabal Awlia & 272 & 195 & 71.7 & 36.1 & $<0.001$ \\
\hline Cartoon Kassala & 584 & 291 & 49.8 & & \\
\hline \multicolumn{6}{|c|}{ Attitudes and practices } \\
\hline Jabal Awlia & 272 & 140 & 51.5 & 42.4 & $<0.001$ \\
\hline Cartoon Kassala & 584 & 432 & 74.0 & & \\
\hline \multicolumn{6}{|l|}{$\begin{array}{l}\text { Treatment-seeking } \\
\text { behaviour }\end{array}$} \\
\hline Jabal Awlia & 272 & 47 & 17.3 & 71.0 & $<0.001$ \\
\hline Cartoon Kassala & 584 & 276 & 47.3 & & \\
\hline
\end{tabular}

aTotal number of heads of household interviewed.

${ }^{b}$ Defined as score above the median cut-off score for the sample.

and among $11.7 \%$ (21) of people from southern tribes $\left(P<0.001, \chi^{2}=19.47\right)$.

According to the professional medical staff at the clinics in the 2 camps, the only antimalarial drug used during the period of the study was chloroquine. Overall, $72.3 \%$ of respondents knew about chloroquine for malaria treatment but 246 (28.7\%) stated the dosage incorrectly. Health services were the first resource for $23.5 \%$ of respondents in Jabal Awlia and 64.4\% in Cartoon Kassala; $31.3 \%$ and $2.2 \%$ respectively used chloroquine without consultation. Chloroquine was the second resource for 92.2\% in Jabal Awlia and 2.3\% in Cartoon Kassala.

Regarding treatment-seeking, the study revealed that $79.8 \%$ of mothers in the whole group took the decision to seek treatment but only $10 \%$ of fathers.

\section{Determinant of malaria attacks}

Out of 856 respondents 584 (68.2\%) reported a malaria attack among household members during the previous year, of whom $56.1 \%$ mentioned more than 1 exposure. Table 3 indicates that the frequency of malaria attacks during the previous year was statistically different in the 2 areas. Residents of Jabal Awlia camp had a 4-fold increased risk compared with those residing in Cartoon Kassala.

Housing conditions, sex and age had no association with malaria attacks in the study area. There was increased risk with younger individuals but this was not statistically significant. However, the age group age 41-60 years was associated with a 4fold increased risk compared with those over 60 years.

In contrast, the frequency of malaria attacks was associated with language spoken, tribe, education and food expenditure. Those who spoke the local languages reported the highest percentage $(85.5 \%)$ of malaria attacks during the past year. Speaking only the local language increased the risk almost 3-fold compared with those

المجلة الصحية لشرق المتوسط، منظمة الصحة العالمية، المجلد التاسع، العدد ؟، ب.. 


\begin{tabular}{|c|c|c|c|c|c|c|}
\hline \multirow[t]{2}{*}{ Determinant } & \multirow[t]{2}{*}{$\begin{array}{l}\text { Total } \\
\text { No. }^{a}\end{array}$} & \multicolumn{2}{|c|}{$\begin{array}{l}\text { Malaria attack in } \\
\text { past year }\end{array}$} & \multirow[t]{2}{*}{$\begin{array}{c}\chi^{2} \\
\text { (P-value) }\end{array}$} & \multirow[t]{2}{*}{$\begin{array}{l}\text { Crude OR } \\
(95 \% \mathrm{Cl})\end{array}$} & \multirow[t]{2}{*}{$\begin{array}{l}\text { Adjusted OR } \\
(95 \% \mathrm{Cl})\end{array}$} \\
\hline & & $\begin{array}{c}\text { No } \\
\text { No. (\%) }\end{array}$ & $\begin{array}{c}\text { Yes } \\
\text { No. (\%) }\end{array}$ & & & \\
\hline \multicolumn{7}{|l|}{ Area } \\
\hline Cartoon Kassala & 584 & $196(33.6)$ & $388(66.4)$ & $6.2(0.01)$ & $1.5(1.08-2.08)$ & $4.07(2.49-6.65)^{*}$ \\
\hline Jabal Awlia & 272 & 76 (27.9) & $196(72.1)$ & & & \\
\hline \multicolumn{7}{|l|}{ Sex } \\
\hline Male & 122 & 41(33.6) & $81(66.4)$ & $0.2(0.60)$ & $1.10(0.73-1.65)$ & $1.38(0.84-2.25)$ \\
\hline Female & 734 & $231(31.5)$ & $503(68.5)$ & & & \\
\hline \multicolumn{7}{|l|}{ Age (years) } \\
\hline$>60$ & 14 & $6(42.9)$ & $8(57.1)$ & $7.2(0.07)$ & 1.00 & \\
\hline$<21$ & 136 & 47 (34.6) & $89(65.4)$ & & $1.4(0.46-4.3)$ & $1.49(0.45-4.95)$ \\
\hline $21-40$ & 590 & $194(32.9)$ & $396(67.1)$ & & $1.5(0.5-4.5)$ & $2.08(0.67-6.45)$ \\
\hline $41-60$ & 116 & $25(21.6)$ & 91(78.4) & & $2.7(0.86-8.6)$ & $3.93(1.17-13.18)^{*}$ \\
\hline \multicolumn{7}{|l|}{ Language } \\
\hline Local + Arabic & 635 & $232(36.5)$ & $403(63.5)$ & $29.2(<0.001)$ & 1.00 & \\
\hline Arabic & 62 & $17(27.4)$ & $45(72.6)$ & & $1.5(0.8-2.7)$ & $1.60(0.84-3.07)$ \\
\hline Dinka only & 159 & $23(14.5)$ & $136(85.5)$ & & $3.4(2.1-5.4)$ & $2.71(1.43-5.13)^{*}$ \\
\hline \multicolumn{7}{|l|}{ Tribe } \\
\hline Nuba & 223 & $83(37.2)$ & $140(62.8)$ & $9.2(0.03)$ & 1.00 & \\
\hline Western tribe & 127 & 43 (33.9) & $84(66.1)$ & & $1.15(0.7-1.8)$ & $0.86(0.51-1.48)$ \\
\hline Dinka & 326 & 104 (31.9) & $222(68.1)$ & & $1.2(0.88-1.8)$ & $1.16(0.71-1.88)$ \\
\hline Southern tribe & 180 & 42 (23.3) & $138(76.7)$ & & $1.9(1.2-3.0)$ & $1.94(1.14-3.29)^{*}$ \\
\hline \multicolumn{7}{|l|}{ Education } \\
\hline Basic & 279 & $110(39.4)$ & $169(60.6)$ & $14.2(0.001)$ & 1.00 & \\
\hline Secondary/higher & r 97 & $33(34.0)$ & $64(66.0)$ & & $0.6(0.47-0.88)$ & $1.71(0.93-3.13)$ \\
\hline Illiterate & 480 & $142(29.6)$ & $338(70.4)$ & & $2.5(1.45-4.3)$ & $1.36(0.94-1.95)$ \\
\hline \multicolumn{7}{|l|}{ Housing conditions ${ }^{b}$} \\
\hline Acceptable & 151 & $56(37.1)$ & $95(62.9)$ & $2.3(0.13)$ & $1.33(0.92-1.92)$ & $1.15(0.83-1.59)$ \\
\hline Poor & 705 & $212(30.1)$ & $493(69.9)$ & & & \\
\hline \multicolumn{7}{|l|}{ Food expenditure } \\
\hline $33 \%$ income & 64 & $31(48.4)$ & $33(51.6)$ & $11.1(0.03)$ & 1.00 & \\
\hline $25 \%$ income & 20 & $9(45)$ & $11(55)$ & & $1.14(0.4-3.14)$ & $1.16(0.35-3.82)$ \\
\hline $50 \%$ income & 201 & $63(31.3)$ & $138(68.7)$ & & $2.0(1.15-3.6)$ & $2.11(1.08-4.11)^{*}$ \\
\hline All income & 536 & $159(29.7)$ & $377(70.3)$ & & $2.2(1.3-3.7)$ & $1.97(1.09-3.61)^{*}$ \\
\hline No income & 35 & $10(28.6)$ & 25 (71.4) & & $2.3(0.97-5.7)$ & $1.57(0.58-4.21)$ \\
\hline
\end{tabular}

*Statistically significant at $\mathrm{P}<0.05$.

${ }^{a}$ Total number of heads of household interviewed.

${ }^{b}$ Presence of windows, surrounding walls, type of building, number of rooms. 
speaking Arabic as well as the local language, and belonging to the southern tribes increased the risk almost 2-fold compared with other tribes. History of malaria attacks among household members was highest (70.4\%) among the illiterate respondents. Moreover, those spending half or all of their income on food were at a significantly higher risk of malarial attacks than those with less severe economic constraints.

As illustrated in Table 4, knowledge, attitudes and practices about malaria had no influence on malaria attacks, except for the method of obtaining water. Malaria attacks were significantly associated with obtain- ing water from carts. The respondents whose families obtained water this way had a 4.7-fold increased risk of a malaria attack during the previous year than those getting water from wells.

Out of 584 individuals reporting a previous attack of malaria among household members, $79.1 \%$ perceived malaria as a serious disease and $78.1 \%$ (456) described fever as the predominant symptom associated with malaria. The number of febrile cases reported during the survey was 157 (18.3\%). Only $70 \%$ of those with family members previously suffering a malaria attack knew the correct chloroquine dosage,

\begin{tabular}{|c|c|c|c|c|c|c|}
\hline \multirow[t]{2}{*}{ Determinant } & \multirow[t]{2}{*}{$\begin{array}{l}\text { Total } \\
\text { No. }^{a}\end{array}$} & \multicolumn{2}{|c|}{$\begin{array}{l}\text { Malaria attack in } \\
\text { past year }\end{array}$} & \multirow[t]{2}{*}{$\chi^{2}(P$-value $)$} & \multirow[t]{2}{*}{$\begin{array}{l}\text { Crude OR } \\
(95 \% \mathrm{Cl})\end{array}$} & \multirow[t]{2}{*}{$\begin{array}{l}\text { Adjusted OR } \\
(95 \% \mathrm{CI})\end{array}$} \\
\hline & & $\begin{array}{c}\text { No } \\
\text { No. (\%) }\end{array}$ & $\begin{array}{c}\text { Yes } \\
\text { No. (\%) }\end{array}$ & & & \\
\hline \multicolumn{7}{|l|}{ Knowledge } \\
\hline Poor & 370 & $114(30.8)$ & $256(69.2)$ & $0.28(0.60)$ & $1.08(0.81-1.44)$ & $1.12(0.78-1.60)$ \\
\hline Good & 486 & $158(32.5)$ & $328(67.5)$ & & & \\
\hline \multicolumn{7}{|l|}{$\begin{array}{l}\text { Attitude and } \\
\text { practices }\end{array}$} \\
\hline Poor & 284 & 87 (30.6) & $197(69.4)$ & $0.26(0.61)$ & $1.08(0.79-1.47)$ & $0.93(0.64-1.33)$ \\
\hline Good & 572 & 185 (32.3) & $387(67.7)$ & & & \\
\hline \multicolumn{7}{|c|}{$\begin{array}{l}\text { Treatment-seeking } \\
\text { behaviour }\end{array}$} \\
\hline Poor & 533 & $171(32.1)$ & $362(67.9)$ & $0.06(0.80)$ & $0.96(0.7-1.2)$ & $1.10(0.7-1.6)$ \\
\hline Good & 323 & $101(31.3)$ & $222(68.7)$ & & & \\
\hline \multicolumn{7}{|l|}{ Source of water } \\
\hline Well & 452 & $186(41.2)$ & $266(58.8)$ & $38.8(<0.001)$ & $2.58(1.91-3.50)$ & $4.67(2.81-7.76)^{\star}$ \\
\hline Cart & 404 & $86(21.3)$ & $318(78.7)$ & & & \\
\hline \multicolumn{7}{|l|}{ Keeping water } \\
\hline No & 805 & 255 (31.8) & $548(68.2)$ & $0.002(0.90)$ & $0.98(0.54-1.78)$ & $1.61(0.79-3.28)$ \\
\hline Yes & 53 & 17 (32.1) & $36(67.9)$ & & & \\
\hline
\end{tabular}

*Statistically significant at $\mathrm{P}<0.05$.

${ }^{a}$ Total number of heads of household interviewed.

المجلة الصحية لشرق المتوسط، منظمة الصحة العالمية، المجلد التاسع، العدد ع، ب... 
and $67.6 \%$ of them stated that mosquito bites were the cause of malaria. The number of people reporting a previous attack of malaria was comparable between users and non-users of bednets.

\section{Discussion}

Malaria is one of the major causes of mortality and morbidity in developing countries. The situation is worsening due to environmental and biological changes occurring simultaneously with population movement.

We carried out this study in order to identify some of the risk factors associated with malaria, especially among the poorest communities, in this case displaced people.

In the 2 camps of the study area, Jabal Awlia and Cartoon Kassala, malaria attacks among household members were more frequently reported by people speaking only the local language; this may be due to the fact that they were less aware about malaria since information was conveyed in Arabic, a language they did not understand. Malaria attacks were more frequent among illiterate people than among others. Again, this is probably because they were less aware about the disease and the preventive measures that should be undertaken. It is apparent from our study that these socioeconomic factors (illiteracy and poor knowledge) were risk factors for suffering a malaria attack. These factors have been shown to predispose to malaria in previous studies in Africa [8] and in parts of Asia and Latin America [9-12].

The people interviewed in Jabal Awlia had good knowledge of malaria, indicating that they were familiar with the disease. However, they had poor attitudes and practices towards the disease. Of all the respondents, more than $70 \%$ believed malaria was a serious disease and fever was identified by two-thirds of the population as the predominant symptom. Similar findings have been reported in previous studies [12,13]. We have reported in another paper that poor knowledge about malaria was a significant risk factor for death from malaria among household members of this sample [7].

The association between malaria attacks and source of water was evident in our study. The results showed that individuals obtaining water by cart reported a higher incidence of malaria attacks in the previous year, though keeping water was not found to be related to the incidence of malaria. It is possible that respondents were in fact keeping water but they were not mentioning this because many (66\%) knew that stored water can create breeding sites for mosquitoes. Mosquito bites were identified correctly as the cause of malaria by more than $70 \%$ of the respondents in the present study; similar findings have been reported in other studies $[13,16,17]$. Deaths from malaria among household members in this sample were higher when water was obtained from carts than wells (chi-squared analysis) although it was not a significant risk in the regression analysis [7].

The finding that more than $40 \%$ of the sample delayed seeking treatment for malaria is in agreement with earlier reports [15]. Reasons mentioned for the delay included lack of money and waiting for improvement following the use of traditional remedies. The practices of self-medication in the present study were probably related to cultural beliefs and the cost of medical services; a similar finding has been reported previously [14].

The frequency of malaria attacks during the previous year did not differ significantly between users and non-users of bednets. This may be because only a small propor-

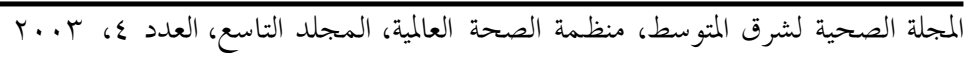


tion (18.8\%) of the sample owned bednets because the majority reported that they are prohibitively expensive.

\section{Conclusion and recommendations}

The study showed that tribe, language, source of water, education and food expenditure were the main risk factors for suffering a malaria attack in displaced people.

We conclude that education interventions for malaria are needed that address all tribes. Local languages should be used to alter the attitudes and practices of the various tribes and encourage patients to present for treatment of malaria at an early stage of the disease. Provision of a safe water supply to displaced populations is essential. Removal of economic barriers, especially patient charges for health care, is essential for improvement of treatmentseeking practices. Efforts should be made to promote the use of bednets and to seek ways to make them more affordable. Finally, further research into cultural beliefs about malaria will promote compatibility of beliefs with appropriate treatment.

\section{Acknowledgements}

We are grateful to the staff of National Malaria Control Administration, the community health promoters at the health centres in the camps and the members of households enrolled in this study for their collaboration. Our thanks are due to Dr. Siddig Shahin, University of Khartoum, for his help in analysing the data and Dr. Bilgis Badri, Ahfad University for Women.

This study received financial support from the Joint WHO Joint Mediterranean Region (EMRO), Division of Communicable Diseases (DCD) and the WHO Special Programme for Research and Training in Tropical Diseases (TDR): The EMRO/ DCD/TDR Small Grant Scheme for Operational Research in Tropical and Communicable Diseases project ID36. This financial contribution is gratefully acknowledged.

\section{References}

1. The world health report 2002: reducing risks, promoting healthy life. Geneva, World Health Organization, 2002.

2. Mwageni E et al. Household wealth ranking and risks of malaria mortality in rural Tanzania. In: Third MIM Pan-African Conference on Malaria, Arusha, Tanzania, 17-22 November 2002. Bethesda, Maryland, Multilateral initiative on malaria: abstract 12 .

3. Murphy SC, Breman JG. Gaps in the childhood malaria burden in Africa: cerebral malaria, neurological sequelae, anemia, respiratory distress, hypoglycemia, and complications of pregnancy. American journal of tropical medicine and hygiene, 2001, 64(1-2 suppl.):5767.

4. Kondrachine AV, Trigg PI. Global overview of malaria. Indian journal of medical research, 1997, 106:39-52.

5. National Health Information Centre. Annual health statistical report. Khartoum, Federal Ministry of Health, 2001.

6. Guthmann JP et al. Does chloroquineresistance occur in displaced populations of southern Sudan? Tropical doctor, 1996, 26(2):89-90.

7. Saeed IE, Ahmed ES. Determinants of malaria mortality among displaced people in Khartoum state, Sudan. East-

المجلة الصحية لشرق المتوسط، منظمة الصحة العالمية، المجلد التاسع، العدد ع، ب... 
ern Mediterranean health journal, 2003, 9:593-9.

8. Koram KA et al. Socio-economic risk factors for malaria in a peri-urban area of The Gambia. Transactions of the Royal Society of Tropical Medicine and Hygiene, 1995, 89 (2):146-50.

9. Banguero $\mathrm{H}$. Socio-economic factors associated with malaria in Colombia. Social science and medicine, 1984, 19: 1099-104.

10. Buttraporn P, Sornmani S, Hungsapruek T. Social, behavioural, housing factors and their interactive effects associated with malaria occurrence in east Thailand. Southeast Asian journal of tropical medicine and public health, 1986, 17: 386-92.

11. Fungladda $\mathbf{W}$ et al. Socio-demographic and behavioural factors associated with hospital malaria patients in Kanchanaburi, Thailand. Journal of tropical medicine and hygiene, 1987, 90: 233-7.

12. Faye $O$ et al. Connaissances et circuits thérapeutiques relatifs au paludisme en zone rurale sénégalaise [Knowledge and treatment of malaria in rural Senegal]. La medicina tropical, 1997, 57(2):161-4.

13. Hla-Shein et al. The level of knowledge, attitude and practices in relation to malaria in Oo-do village, Myanmar. Southeast Asian journal of tropical medicine and public health, 1998, 29(3):546-9.

14. Foster S. Treatment of malaria outside the formal health services. Journal of tropical medicine and hygiene, 1995, 98(1):29-34.

15. McCombie C. Treatment seeking for malaria: a review of recent research. Social science and medicine, 1996, 43(6):93345.

16. Govere $\mathrm{J}$ et al. Community knowledge and perceptions about malaria and practices influencing malaria control in Mpumalanga Province, South Africa. South African medical journal, 2000, 90(6):611-6.

17. Karanja et al. Knowledge and attitude to malaria control and acceptability of permethrin impregnated sisal curtains. East African medical journal, 1999, 76(1):42-6. 